\title{
Polish Censorship during the Late Stalinist Period
}

\author{
K. Kamińska-Chetminiak
}

For citation: Kamińska-Chełminiak K. Polish Censorship during the Late Stalinist Period. Vestnik of Saint Petersburg University. History, 2021, vol. 66, issue 1, pp. 245-259.

https://doi.org/10.21638/11701/spbu02.2021.115

The aim of the study is to present selected aspects of the history of censorship in Poland during the Stalinist period (1948-1956). The article presents the circumstances of the establishment of the censorship office in Poland - the Central Office for the Control of Press, Publications and Events (GUKPPiW) - which was set up in January 1945 and operated throughout the period of the Polish People's Republic, until April 1990. The article also gives an answer to the question about the role of the so-called Soviet advisers who came to Lublin in December 1944 and took full control of the process of creating state censorship. The employees of the Soviet censorship sent from Moscow were tasked with creating an institution that would control the media and operate according to the mechanisms established in the USSR. In the process of organizing the censorship apparatus, the Polish communists played a marginal and servant role towards the Soviet military (including General N. Bulganin) and advisers who came from Moscow. The most important decisions were made by the employees of Glavlit, whose recommendations were treated by the management of the Polish Workers' Party as orders. Glavlit officers, who arrived in Lublin in December 1944, recruited censorship employees, developed instructions for them, rules for publishing and issuing printed works and drafted a decree on the control of the press, publications and performances, a draft order of the minister of public security regarding the introduction of censorship. The work also describes the process of recruiting censors, as well as the reasons and scope of censorship interventions.

Keywords: the Central Office for the Control of Press, Publications and Events, the Stalinist period in Poland, censorship office in Poland.

\section{Польская цензура в эпоху позднего сталинизма}

\section{К. Каминьска-Хелминяк}

Для цитирования: Kamińska-Chetminiak K. Polish Censorship during the Late Stalinist Period // Вестник Санкт-Петербургского университета. История. 2021. Т.66. Вып. 1. С.245-259. https://doi.org/10.21638/11701/spbu02.2021.115

Целью исследования было представить отдельные аспекты истории цензуры в Польше в сталинский период (1948-1956). В статье раскрыты обстоятельства создания в Польше центра цензуры - Главного управления по контролю над прессой, публикациями

Kamila Kamińska-Chetminiak - Dr. Hab., University of Warsaw, 2/4, ul. Bednarska, Warsaw, 00-310, Poland; ka.kaminska@uw.edu.pl

Камила Каминьска-Хелминяк - хабилитированный д-р, Варшавский университет, Польша, 00-310, Варшава, ул. Беднарска, 2/4; ka.kaminska@uw.edu.pl

(C) St. Petersburg State University, 2021 
и зрелищами (ГУКППиЗ), - которое было сформировано в январе 1945 г. и действовало на протяжении всего периода Польской Народной Республики до апреля 1990 г. Перед ним стояла задача защиты интересов правящей партии и ее союзников. Также был дан ответ на вопрос о роли так называемых советских советников, которые прибыли в Люблин в декабре 1944 г. и взяли под полный контроль процесс создания государственной цензуры. Присланным из Москвы работникам советской цензуры надлежало организовать институт, который бы контролировал СМИ и действовал в соответствии с механизмами, установленными в СССР. Польским коммунистам отводилась второстепенная, служебная роль в отличие от советских военных (включая генерала Булганина, генерала Шатилова) и советников из Москвы. Наиболее важные решения принимали сотрудники Главлита, чьи поручения руководство Польской рабочей партии рассматривало как приказы. Служащие Главлита, прибывшие в Люблин в декабре 1944 г., наняли сотрудников цензуры, разработали для них инструкции, правила издательства и публикации печатных произведений, постановление о контроле над прессой, публикациями и зрелищами, проект приказа министра общественной безопасности о введении цензуры. Они составили отчет об изъятии враждебной и вредной литературы из публичных библиотек, о политических ошибках в прессе, а также список газет и журналов, издаваемых в Польше. Кроме того, в статье описан процесс набора цензоров, а также причины и масштабы цензурного вмешательства.

Ключевые слова: цензура в Польше, Главное управление по контролю над прессой, публикациями и зрелищами, советские советники, сталинизм.

The paper presents selected aspects of the history of censorship in Poland during the Stalinist period. The starting point was to explore the genesis of the Polish censorship office - the Central Office for the Control of Press, Publications and Performances (GUKPPiW) - which was established in January 1945 and operated throughout the period of the Polish People's Republic (PRL), until April 1990. An important aspect of the article is an outline of circumstances surrounding the establishment of GUKPPiW (between January and November 1945, the office was called the Central Press Control Bureau), including the role of the so-called Soviet advisers who arrived in Lublin in December 1944, where until January 1945 the Polish Committee for National Liberation, formed by Polish communists on the orders of Joseph Stalin, resided, and took full control of the process of creating state censorship. The study also provides answers to the question about the censor recruitment process, and analyses the causes and scope of censorship interference and the sources of instruction.

Although the topic of state censorship in Poland has already been discussed in the literature on the subject, thanks to the search in Polish archives and the analysis of Russian documents, the author of the work has managed to present many new facts and threads indicating, for example, how marginal the role of Polish communists, even that of Bolesław Bierut, a member of the authorities of the Polish Workers' Party (PPR), and President of Poland in 1947-1952, was in the process of creating the control apparatus. The burden of setting up the censorship apparatus in Poland was almost fully borne by the employees of the Soviet censorship - Glavlit (Главлит) - who for several months of their stay in Poland, between December 1944 and April 1945, formed the foundations of the new office. The mechanism of operation of the new office was to be modelled on the Soviet one.

One more aspect of the work requires clarification - the turning point of the discussed issue. For many years, Polish historians have been discussing the description of the system that prevailed in Poland after 1944. Dariusz Jarosz, a researcher of the social his- 
tory of Poland after 1945, the author of numerous books on this subject, noted that while we more or less know what Stalinism means in the Soviet Union and there is, in principle, agreement as to its chronological framework, in the case of Poland it is a more complex matter. The concept of Stalinism is far from precise and is used quite freely in the scholarship $^{1}$. Historians who limit the period of Stalinism in Poland to 1948-1955/1956 are accused of believing that the first post-war years of building the communist system in Poland were relatively mild, and the terror of the new government was aimed only at narrow social groups not accepting the changes taking place in the country. Some historians of the recent history of Poland believe that the period of Stalinism should be associated with 1944-1956, and narrowing it down to the period of 1949-1954 serves the conviction that the beginnings of communist rule in Poland were almost democratic ${ }^{2}$. This is the opinion of Jerzy Eisler, a historian of the political history of Poland after 1945, who expressed the view that the narrowing of the Stalinist period to 1948-1955 was typical mainly for researchers from the former Polish United Workers' Party (PZPR). The already mentioned Dariusz Jarosz, who placed Stalinism in the time period between 1948 and $1956^{3}$, stands in some way in opposition to the above opinions. Andrzej Friszke, a researcher of the history of the opposition in Poland after 1945, who called the years 1944-1948 the time of building the foundations of a totalitarian system, and considered 1948 to have been the beginning of Stalinism, shares the same view ${ }^{4}$. On the other hand, Wojciech Roszkowski, the author of many books on the political history of Poland and the world, called the years 1948-1953 the "apogee of Stalinism", which seems to be an intermediate solution between the extension of the entire Stalinism to 1944-1956, and its confining only to the period of $1948-1955^{5}$. Being aware of the lack of consensus among Polish historians as to the initial turning point of Stalinism, the author of the work decided to limit this period to the years 1949-1956 because from the point of view of censorship, there is a clear change in the tactics and strategy of its operation after 1948 (this will be discussed further on in the article). Thus, the beginning of work was 1948, when the consolidation of power was achieved as a result of the merger of the Polish Socialist Party (PPS) and the Polish Workers' Party, which resulted in the creation of a mono-party- the Polish United Workers' Party. The closing date is 1956 when the de-Stalinisation process began to intensify in Poland. The election of Władysław Gomułka as the first secretary of the Polish United Workers' Party in October 1956 is generally treated as the end of the thaw process in Poland and a return to some Stalinist method of exercising power.

Institutions responsible for censoring the media in countries that found themselves in the Soviet sphere of influence and were incorporated into the USSR were established by order of Joseph Stalin during the war ${ }^{6}$. They were created by functionaries of the So-

\footnotetext{
1 Jarosz D. Polacy a stalinizm 1948-1956. Warszawa, 2000. P. 6.

2 Eisler J. Co nam zostało z tamtych lat. Dziedzictwo PRL. Warszawa, 2016. P. 174. See also: Kersten K. Stalinizm w Polsce // Tygodnik Solidarność. 1989. Vol.3. P. 8.

${ }^{3}$ Jarosz D. Rzeczy, ludzie, zjawiska. Studia z historii społecznej stalinizmu w Polsce. Warszawa, 2017. See also: Werblan A. Stalinizm w Polsce. Warszawa, 2009, P. 53; Garlicki A. Stalinizm. Warszawa, 1993, P. 24-26; Czubiński A. Polska i Polacy po II wojnie światowej. Poznań, 1998, P. 256-350.

${ }^{4}$ Friszke A. Polska. Losy państwa i narodu 1939-1989. Warszawa, 2003. P. 161-163.

${ }_{5}^{5}$ Roszkowski W. Najnowsza historia Polski 1945-1980. Warszawa, 2003. P. 199.

${ }^{6}$ Goriaeva T. M. Blitskrig v Pol'shu // Iskliuchit' vsiakie upominaniia... Ocherki istorii sovetskoi tsenzury / ed. by T. M. Goriaeva. Minsk; Moscow, 1995. P. 107.
} 
viet censorship Glavlit ${ }^{7}$ - and, to a lesser extent, by local communists. However, unlike Poland, the directorates of the control offices in individual Soviet republics were subordinated to the Glavlit headquarters in Moscow. In the case of Poland, the task of organizing state censorship was entrusted to the so-called Soviet advisers, adequately trained and prepared to work in the censorship and propaganda section ${ }^{8}$. Jakub Berman, Bolesław Bierut's trusted man, who invited censors from Glavlit to Poland, spoke about the role of Soviet advisers in the final period of the war. Berman stated that the recommendations of the Soviet censors were treated as orders. Stalin believed that their presence was not negotiable: Soviet censors were supposed to help Polish communists and even save them. Berman was of the opinion that the agreement or disagreement of the Polish communists did not matter much 9 . The margin of independence of the Polish communists from Stalin was very narrow, and the consequence of the disobedience could be the "replacement of the team". In turn, Edward Ochab, like Berman, a close associate of Bierut, expressed the view that Soviet advisers had the decisive voice in many ministries, especially in the bodies of the Ministry of Public Security, “...they often did not know the Polish language and knew nothing about our difficult history"10.

The employees of the Soviet censorship sent from Moscow were tasked with creating an institution that would control the media and operate according to the mechanisms established in the USSR. According to Tatiana Goriaeva, a researcher of Soviet censorship and the author of several books on the subject, one of the reasons for the formation of a control office in Poland was the growing information in the West about Soviet activities in Poland during World War $\mathrm{II}^{11}$. Stalin wanted to block information unfavourable to the Soviet Union which leaked to the Western media, especially on the eve of the Yalta conference. Among the reasons for the creation of civil censorship in Poland, apart from the already existing military one, it is also necessary to mention the prevention of disclosure of military secrets in the press, the enhancement of the image of the Soviet Union and the Red Army, and propaganda discrediting the Polish government in London. The documents published in the work entitled Radziecka propaganda w końcowy etapie wojny (1943-1945). Zbiór dokumentów (Soviet propaganda in the final stage of the war (1943-1945). Collection of papers) show that the director of the Soviet censorship,

7 Glavnoe upravlenie po delam literatury i izdatel'stv (Главное управление по делам литературы и издательств), Goriaeva T. M. Blitskrig v Pol'shu. P. 14. About Glavlit see inter alia: Istoriya sovetskoy politicheskoy tsenzury. Dokumenty i kommentarii / ed. by T. M. Goriaeva. Moscow, 1997; Politicheskaia tsenzura v SSSR. 1917-1991 gg. / ed. by T.M. Goriaeva. Moscow, 2009; Vladimirov L. "Glavlit": how the soviet censors work // Index. 1972. Vol. 1, no. 3/4. P. 31-43; Tsenzura v Sovetskom Soyuze, 1917-1991. Dokumenty / ed. by A. V. Blium. Moscow, 2004; Blium A. V. Sovetskaia tsenzura v epokhu total'nogo terrora. 1929-1953. Moscow, 2000; Sovetskaia propaganda na zavershaiushchem etape voiny (1943-1945 gg.): sbornik dokumentov / eds A. Ya. Livshin, I. B. Orlov. Moscow, 2015. - Only a few articles about soviet censorship have been published in Polish, see: Goban-Klas T. Literacki Gułag: Gławlit, czyli najwyższe stadium cenzury // Piśmiennictwo - systemy kontroli - obiegi alternatywne / eds G. Borkowska, K. Stadnik: in 2 vols. Vol. 1. Warszawa, 1992. P. 46-59; Gardocki W. Wymiana idei i doświadczeń. Współpraca Głównego Urzędu Kontroli Prasy, Publikacji i Widowisk z Gławlitem // Wschodni Rocznik Humanistyczny. 2014. Vol. X. P. 41-49.

${ }^{8}$ About the history of censorship in Poland after II world war see: Kamińska-Chetminiak K.: 1) Cenzura w Polsce 1944-1960. Organizacja, kadry, metody pracy. Warszawa, 2019; 2) Central Office of Press Control / Main Control Office of Press, Publication and Performances - background, audit scope and Staff // Acta Universitatis Lodziensis. Folia Litteraria Polonica. 2017. Vol. 45, iss. 7. P. 309-316.

9 Torańska T. Oni. Warszawa, 1990, P. 75.

10 Ibid. P. 198.

11 Goriaeva T.M. Blitskrig v Pol'shu. P. 108. 
Nikołaj Sadczikow, in a letter to the Central Committee of the VKP(b), complained that the press of the states incorporated into the USSR published information covered by military secrecy (names of individual military units, army displacement). One newspaper even reported on the construction of cyclotrons, while another published an article about "leading companies in countries like America and England"12. The documents also show that Stalin was aware of the negative mood of the local population in the countries in the Soviet sphere of influence and made efforts to prevent the negative image of the Red Army from spreading to the pages of the Western press and radio broadcasting ${ }^{13}$.

An important reason for sending the Glavlit employees to Poland was the desire to accelerate work related to the monopolization of media. The minutes of the meetings of the Political Bureau of the Central Committee of the Polish Workers' Party from 19441945 show that Stalin had limited confidence in the party leadership, therefore he entrusted the establishment of the censorship office to professionals with more experience in propaganda than Polish communists. The task of the Soviet censors was to organize a censorship office modelled on the Soviet pattern and to speed up the pace of work on an institution controlling the media, which was to be one of the pillars of securing Soviet interests in Poland. The result of the work of the Soviet censors was the establishment of the Central Press Control Bureau (CBKP) on January 19, 1945, by order of the Minister of Public Security, Stanisław Radkiewicz, which initially was subordinate to the Ministry of Public Security (MBP) $)^{14}$. The Central Press Control Office set up on 19 January 1945 was almost entirely dominated by members of the Polish Workers' Party ( 80 percent of the staff). The first censors were selected from among the officers of the Ministry of Public Security, the more so as until mid-November 1945 the office was subordinate to the Ministry of Public Security. The employees of the Ministry of Public Security, and thus also censors, came from social advancement. 85 percent of staff had primary or incomplete primary education, and only 1 percent had higher education ${ }^{15}$. On November 15, 1945, the CBKP was transformed by a resolution of the Council of Ministers into the Central Office for the Control of Press, Publications and Performances, which was placed under the authority of the Presidium of the Council of Ministers, although in practice it was still subordinate to Jakub Berman ${ }^{16}$.

While the party's tactics just after the war were characterized by a relative tolerance towards certain circles, which Jakub Berman called a "course for appeasement" in May 1949 , resulting from the desire to win over the broad masses of society, 1949 was a turning point that marked the parting with camouflage policy. In the first years after the war, despite the existence of an extensive apparatus of terror against the independence underground and the Polish People's Party, the non-communist press (with the exception of the Polish People's Party [PSL] press), including the Catholic press, could perform its tasks relatively freely. Censorship interventions were comparatively few. The attitude of the cen-

\footnotetext{
12 Sovetskaia propaganda na zavershaiushchem etape voiny (1943-1945 gg.). P. 176.

13 See: Major Ponomarev's report on the activities of the Red Army in the territories liberated from German occupation in February-March 1945 // Ibid. P. 156.

${ }^{14}$ Księga bezprawia. Akta normatywne kierownictwa Resortu Bezpieczeństwa Publicznego (19441956) / ed. by B. Kopka, introduction A. Paczkowski. Warszawa, 2011, P.75-76; Główny Urząd Kontroli Prasy 1945-1949 / ed. by D. Nałęcz. Warszawa, 1994. P. 27.

15 Borowiec J. Aparat bezpieczeństwa a wojskowy wymiar sprawiedliwości. Rzeszowszczyzna 19441954. Warszawa, 2004. P.78.

16 Główny Urząd Kontroli Prasy 1945-1949. P. 17.
} 
sors themselves towards the members of the editorial office was also different. Censors were more likely to make concessions, generally did not consider themselves infallible, did not avoid discussions with editors, often a censor convinced of the editorial staff's arguments withdrew his interference. Usually, censors kept their deadlines, and controlled materials were quickly returned to the editorial office.

A significant change in the functioning of the censorship apparatus took place at the end of 1949, which was related to the $3^{\text {rd }}$ Plenary Meeting of the PZPR Central Committee (November 11-13, 1949) and the $3^{\text {rd }}$ Session of the Communist Party Information Bureau in Budapest. During the plenum, the $1^{\text {st }}$ secretary of the Central Committee of PZPR, Bolesław Bierut, delivered two speeches, opening and closing. The papers delivered by Bierut can be summarized in one sentence - the enemy lurks everywhere, so be careful. The enemies included: imperialist foreign centres; informers and spies who "lick the shoes of their American masters"; all foreign ideologies; petty bourgeois influences; social democratic members of the Polish Socialist Party; foreign agents; Tito cliques; the bourgeoisie; fascist degeneration; Trotskyist-Bukharin-Soviet bloc; rotten liberalism; tolerance and nationalist and right-wing deviations. Psychosis related to the activities of the class enemy and foreign agents penetrating their own environment almost crept into the ranks of the censors. As a result of ideological paranoia, even the inconspicuous mistakes of the typesetter were treated as subversive activities having far-reaching consequences for the guilty (dismissal, investigation of the Soviet Office, trial).

One of the consequences of the Third Plenum was increased vigilance towards typesetters working in printing houses, whose mistakes, even inconspicuous, were treated as activities detrimental to the party and the state. While in the 1940s oversight was called an "inevitable necessity", in the 1950s it was already a diversion. Party resolutions were translated into the daily work of censors. During the briefings, the duty to be vigilant and to fight the class enemy, who might as well be lurking in the printing house, was increasingly emphasized. A number of typesetting errors resulted in an investigation by the Security Office (UB) and the Voivodeship Committee of the PZPR, for example, when a note about the unveiling of the Lenin monument was published in one of the local newspapers. As a result of a typist's error, the pseudonym of Vladimir Ilyich Ulyanov was so distorted that instead of Lenin, "Len'" (lazybones) was created. Another case concerned an article that had been checked and corrected previously by a censor, but was distorted at the stage of typesetting work. The lines of the text shifted, thanks to which the reader was informed that "the Staff of the Soviet Army during the hostilities worked closely with the Gestapo"17. The Security Office's investigation also ended with the typesetting scandal that took place in Poznan. The sentence from the press article saying "the Communist Party of the Soviet Union is conscience and honour" was distorted in such a way that "humour" was inserted in place of "honour". Due to the seriousness of the mistake, it was considered not only a simple typo (correction error), but an effect of an enemy's subversive activity ${ }^{18}$. Another case of serious misconduct was that one of the marine journals included the phrase "as a result of the Soviet provocation", instead of "as a result of the Soviet proposal". The case

17 Narada krajowa naczelników Wojewódzkich Urzędów Kontroli Prasy, Publikacji i Widowisk w czerwcu 1951 r. Protokół // Archiwum Akt Nowych (AAN). Główny Urząd Kontroli Prasy, Publikacji i Widowisk (GUKPPiW). Ref. no. 5. P. 83.

18 Sprawozdania okresowe WUKPPiW za rok 1953 (Olsztyn, Opole, Poznań, Rzeszów, Szczecin, Wrocław). Recenzje książek, pisma instrukcyjne // AAN. GUKPPiW. Ref. no. 11. P. 201. 
was discussed by the Provincial Police Headquarters of the PZPR, and also at the briefing, and the head called it a diversion.

Until mid-November 1945, when the censorship office was subordinate to the Ministry of Public Security, censors were recruited mainly from among ministry officials, however, employees of the Security Offices were not suitable for censorship because they were hired from the lowest strata of society, and in terms of education - as assessed by the MBP minister himself - the staff presented themselves "miserably"19. People deprived of appropriate education who were promoted went to the Ministry of Public Security (in $1945,1 \%$ of officers had incomplete higher education, $14 \%$-incomplete secondary and secondary, $49 \%$ - primary education, $36 \%$ - incomplete primary), and reluctance of the society against the repressive apparatus meant that common bandits, people of low moral and intellectual level, and even the illiterate were admitted to the office ${ }^{20}$. A large group of lower-level officers of the Ministry of Public Security came from plebeian strata, mainly from the border of villages and cities. They were mostly very young people, without political tradition, often without any profession or education; they were characterized by: young age, low education, lack of qualifications and life experience, fanaticism, arrogance and cleverness ${ }^{21}$.

An analysis of the personal files of censors and transcripts from meetings of the CBKP and then GUKPPiW management leads to the conclusion that the value of an ordinary censorship worker in the first years after the war was largely determined by higher education (in 1945, 17\% of censors from GUKPPiW had it, but over time this percentage dropped to $1 \%$ level in 1948), the willingness to work and the acceptance of the new political reality. Contrary to appearances, belonging to a party was not the most important thing, and the management of the office believed that a non-party censor could be as good as a party censor ${ }^{22}$. In the later period of Stalinism, the attitude towards non-party members would change dramatically, and the lack of the PZPR ID was a serious obstacle at work, which hampered promotion and completely disqualified people with "managerial" ambitions. The set of features of an ideal censor was as follows: political and ideological preparation, care, diligence, insight, perceptiveness, dedication, discipline and independence.

With the onset of Stalinism in Poland, the requirements for censors recruited to work changed. The ideological commitment had become the most important requirement for control officers. The Marxist worldview was a sine qua non condition for working in censorship. The motivations for work had to be purely ideological, the censors were to be characterized by a sense of mission because the employees of censorship offices were to

19 Aparat bezpieczeństwa w Polsce. Kadra kierownicza 1944-1956: in 3 vols. Vol. 1 / ed. by K. Szwagrzyk. Warszawa, 2005. P.72.

${ }^{20}$ Charczuk W. Instrukcja dla oficerów śledczych Urzędu Bezpieczeństwa z 1945 roku // Wschodni Rocznik Humanistyczny. 2011. Vol. VII. P.377-378. See also: Borowiec J. Aparat bezpieczeństwa a wojskowy wymiar sprawiedliwości. P. 78.

21 Ibid. P. 80.

22 On June 1, 1948, 202 employees of the Central Office for the Control of Press, Publications and Events and local offices belonged to the party (PPR or PPS), and 145 were nonparty. Odprawa naczelników Wojewódzkich Urzędów Kontroli Prasy, Publikacji i Widowisk w dniach 4-5 VI 1948 r. // AAN. GUKPPiW. Ref. no.3. P.37. 
be, as Ferdinand Chaber, the deputy head of the Press and Publishing Department of the Central Committee of PZPR instructed, "an apparatus designed to expose the enemy" 23 .

While in the 1940s, when state censorship was in statu nascendi, there were cases of hiring politically unskilled people, or even - though rarely - by chance, in the years of Stalinism this type of recruitment became almost impossible (which does not mean that there were no such cases, especially in the provinces). The candidate was checked from all sides. His biography, roots, views and likings were analysed. The so-called political background, and membership in a party guaranteed that the censor would meet the ideological requirements of the authorities and would treat his duties in a conscientious manner. Particularly valuable, apart from higher education, was the ideological and political background and party training. When a newly hired censor was admitted to the control office, the head assessed his knowledge, political background, willingness to discuss, vigilance, intelligence, and even temperament. The heads of the Voivodeship Offices for the Control of Press, Publications and Performances (WUKPPiW) also pointed out whether the candidate for the censor had no clerical tendencies. Religiousness and empathy towards the situation of the clergy disqualified the future censor in advance.

During many years of work, the newly hired censors underwent various trainings to raise their professional and ideological qualifications. During the Stalinist period, the accumulation of all kinds of training and meetings was so large that the work filled most of the average censor's free time. Those who refrained from training were disciplined by the Secretary of the Basic Party Organization (POP) or the head of the office, and information about their reprehensible attitude was sent to GUKPPiW. A disrespectful approach to ideological training could expose the censor to repression by the party apparatus. However, these were rare cases, as the censors of the 1950s were generally characterized by ideological principles, so their responsibilities were treated in terms of patriotic duties.

The basic elements of the censor's ideological training were the so-called briefings that took place every day at the workplace. During the briefings, political instructions, reviews of interference, omissions (fragments of articles overlooked by censors), the provincial, central and communist (most often the Soviet "Pravda") and other instructional materials were discussed.

During ideological training, the information provided to ordinary censors was previously selected and ideologically processed in the appropriate department of the Central Committee of PUWP. The censors had no chance of learning about the Gulag, for example. During the training sessions, they did not raise the wrong topics, generally did not ask embarrassing questions, and did not question the Marxist version of the story as such behaviour was not tolerated by the administration of the office. During the training courses, the censors thoroughly acquainted themselves with the latest history of Poland and the world, properly prepared and taught in the spirit of historical materialism. The basic readings of the censors included works by Joseph Stalin (e.g. Historia Ruchu Robotniczego, Krótki kurs VKP(b), Ekonomia polityczna, XIX Zjazd KPZR, Historia KPZR, Ekonomiczne problemy socjalizmu $w$ ZSRR, Dzieła wybrane, Przemówienie na XIX Zjeździe KPZR), Vladimir Lenin (e.g. Dzieła wybrane), by Karl Marx and Freidrich Engels, as well as by Gieorgi Malenkov (Referat na XIX Zjeździe KPZR) and by Polish communists (especially Bolesław Bierut). A large part of the ideological training was devoted to studies on

${ }^{23}$ Cited after Ferdynand Chaber in Quoted after Ferdynand Chaber // Główny Urząd Kontroli Prasy 1945-1949. P. 88-91. 
the history of the Soviet Union, during which the basic reading was the work Krótki Kurs Historii $\operatorname{VKP}(b)^{24}$.

Despite the fairly intensive training mode, the level of knowledge of the censors in the field of history and culture raised serious reservations about the superiors. The chiefs complained that even the history graduates who entered the provincial audit offices did not have sufficient knowledge. Taking into account the fact that only about $10 \%$ of censors had higher education, the lack of basic historical knowledge should come as no surprise. It can also be assumed, and the author of the work inclines towards this explanation, that a prepared version of history, appropriately bent to the needs of the current state policy, could be a novelty even for history graduates familiar with the history of Poland. The above opinion is confirmed by the words of one of the censors during the training who noted that the common historical knowledge of the average citizen is "burdened with accretions of bourgeois education" which was related to the fact that a group of pre-war professors still lectured at universities ${ }^{25}$.

During the Stalinist period, the line separating private life from party and professional life was very thin. The heads of offices made sure that the censors spent their free time collectively outside work, organizing activities for them, which in fact were closely related to their professional duties. Thus, censors visited museums and exhibitions, attended cinemas and theatres, while exercising secondary control. They also obligatorily took part in marches, rallies and social activities ${ }^{26}$. The head of the office knew about the private life of the censors, their families and health problems, and their addictions. Every month he prepared reports for GUKPPiW, in which he outlined the profiles of censors working in the office. He wrote about their political background, party involvement, approach to the tasks performed, character traits, disadvantages, advantages, education, private problems, family life, and even whether they spoke out during discussions at ideological trainings, and whether they knew Lenin's works.

The private life of the censors was also thoroughly analysed during the meetings of the Basic Party Organizations of the PZPR operating at the censorship offices ${ }^{27}$. POP meetings were to mobilize censors to work more efficiently and effectively and to evaluate their activities so far. The head of offices, often together with the secretary of the POP or the censor from the headquarters controlling the offices subordinate to GUKPPiW, decided how censors should spend their only free day during the week, which was usually Sunday (several hours of training took place on Saturdays).

A phenomenon characteristic of the realities of the functioning of the party apparatus at that time and an element of ideological training was self-criticism at various levels of the party ladder. Self-criticism was exercised by censorship employees, including the chief director of GUKPPiW, during briefings, meetings and in reports. Self-criticism was part

${ }^{24}$ Sprawozdania okresowe WUKPPiW za rok 1953 (Olsztyn, Opole, Poznań, Rzeszów, Szczecin, Wrocław). Recenzje książek, pisma instrukcyjne // AAN. GUKPPiW. Ref. no. 11. P. 125.

25 Sprawozdania okresowe WUKPPiW za rok 1953 (Białystok, Bydgoszcz, Gdańsk, Katowice, Stalinogród, Koszalin, Kielce, Lublin, Łódź) // AAN. GUKPPiW. Ref. no. 10. P. 176.

${ }^{26}$ Sprawozdania okresowe WUKPPiW za rok 1953 (Olsztyn, Opole, Poznań, Rzeszów, Szczecin, Wrocław). Recenzje książek, pisma instrukcyjne // Ibid. Ref. no. 11. P.36.

27 Dariusz Jarosz described a similar mechanism of action of POP on the example of the General Board of the Polish Writers' Union during the Stalinist period, see: Jarosz D. Działalność Podstawowej Organizacji Partyjnej PZPR przy Zarządzie Głównym Związku Literatów Polskich w latach 1949-1953 (w świetle akt własnych) // Mazowieckie Studia Humanistyczne. 1999. Vol. 1. P.5-45. 
of the everyday reality of the censors, who generally treated it as an element of ideological self-improvement. Criticism directed at the leadership of the office and its own was a completely natural and desirable phenomenon in the Stalinist system. Lack of self-criticism led to a loosening of discipline, and as a result, a lower level of mobilization and an increase in the number of omissions during the control. Lack of self-criticism could have caused serious problems, such as removal from office or even, in the case of repeatedly evading self-criticism, expulsion from the party.

At the height of Stalinism, the main cause of censorship interference in the press, with the exception of Catholic publications, was the publication of information classified as state secrets and the so-called typesetting errors. Censors controlled the party press, radio, plays, films, leaflets and books. The control also covered printing companies selling matrices; bookstores; antique shops; libraries; culture clubs (district, i. e. poviat, etc.); poles with advertisements; display cases with newsletters; church kiosks; festivals and other open events; parish announcements hung in churches; church paintings; bazaars.

The censors' duty was to prevent the disclosure of state secrets - both military and economic. Omissions were associated with sanctions (reprimand, rebuke, withdrawal of bonuses, dismissal). During the Stalinist era, the protection of state secrets was generally treated in terms of patriotic obligations. The director of GUKPPiW received instructions from the head of the Military Censorship Department of the General Staff of the Polish Army on securing military secrets, and then passed them on to the heads of local offices. It was forbidden to provide information about the location and type of military units, military infrastructure, training grounds, etc. It was also unacceptable to publish information about the whereabouts of the Red Army units stationed in Poland, their name and organizational size ${ }^{28}$.

Censorship was the party's tool during propaganda campaigns targeting various circles. Censors took part in an action against members and authorities of the Polish People's Party and were responsible for the liquidation of the PSL press, including the most popular periodical - "Gazeta Ludowa". Censors cooperated with the UB/SB in intimidating journalists of the PSL press and contributed - by providing a lot of valuable information - to a series of arrests among editorial offices. The PSL press was harassed by state authorities (the apparatus of repression and censorship) in various ways, ranging from removing most articles and information materials (from $25 \%$ to even $75 \%$ of the whole) from its pages, and ending with beatings and arrests of journalists.

Censors took part in the trials as court experts, and their expert opinions were repeatedly quoted in the indictment; sometimes they formed the basis of the verdict. Censors analysed books, magazines and leaflets supplied to them by officers of the Security Office/Security Service, less often the Citizens' Militia, obtained during searchers of private homes, churches and editorial offices, retrieved from parcels and letters and luggage of travellers crossing the border, or delivered by secret collaborators of the Security Service.

Censors worked closely with the Ministry of Public Security. Thanks to information obtained from censors or secret collaborators employed by, among others in editorial offices, media campaigns were stopped or initiated, and the course of journalists' work was influenced. Information on journalists taking up forbidden topics was collected by the heads of local censorship units and passed on to UB officers. Censors intimidated jour-

${ }^{28}$ Zapiski cenzorskie. Tajemnica wojskowa i gospodarcza 1955-1960 // Archiwum Państwowe w Gdańsku. Wojewódzki Urząd Kontroli Prasy, Publikacji i Widowisk, Ref. no. 1214/3754. P. 26. 
nalists of the Catholic press, creating an atmosphere of uncertainty and fear for their own lives in editorial offices. The co-operation of censors with the UB resulted in repressions directed mainly at Catholic priests, nuns, members of the editorial office of opposition magazines and religious groups. The articles confiscated by the control employees were forwarded, in several copies, to the $5^{\text {th }}$ Department of the Ministry of Public Security, which dealt with the investigation of legal parties and social organizations.

Censors made it difficult and impossible to publish Catholic books, prolonging the printing permit process by several months or even years. They took the typescript for inspection, and then held it for months without informing about the reasons for such a long process. The censors' decisions were variable; once the consent was given, it could be withdrawn within a few days. It was not negotiable, and the publisher's appeal to the Office for Religious Affairs, the prime minister or even the president generally did not bring about positive results. There were cases where the publications provided to the censor were "lost" in the offices. The reasons for the lack of consent to print were incomprehensible, illogical, and sometimes even peculiar. During the Stalinist period, censors systematically intimidated the editors of Catholic magazines and tried to force them to change the profile of the journal, from religious to political, even if it had a strictly liturgical or theological character and was intended for a very small group of priests. During meetings with clergymen, censors repeatedly emphasized that the condition for limiting the number of interferences in Catholic magazines and publications was a change in the editorial line under the threat of closing the magazine and transferring the case to the Security Office.

Not only smaller articles, notes and obituaries were censored, but also papal encyclicals. Censors demanded anti-imperialist prayers and a party-style catechism ${ }^{29}$. School textbooks for religion, catechisms, prayer books, liturgical books and religious pictures were censored. There was no consent given for printing baptism certificates, marriage certificates, invitations to priestly ordinations and business cards for priests. Interferences were made in baptismal registers, deceased registers, marriage registers and marriage re$\operatorname{cords}^{30}$. Censors controlled parish announcements posted in church cabinets, church kiosks, bookstores of Catholic publishing houses, paintings in churches, church sound systems and duplicators owned by curia and church organizations. As a result of the actions of censors dictated by the contemporary politics of the party, in 1952-1953 the Catholic publishing movement collapsed, and the press published by the Church declined. During those years, most Catholic press publications were suspended or closed ${ }^{31}$.

It is worth presenting one more aspect of the functioning of censorship in the People's Republic of Poland - the sources of instruction. The censorship apparatus was an important tool of the PZPR's securing the interests of the party, and the activities of GUKPPiW and WUKPPiW were limited to the implementation of the guidelines of the Central Committee of the PSL, and then the Central Committee of PZPR and the Council of Ministers. It should be pointed out that the censorship office was not an independent entity, and the tasks performed by the control staff were determined at the highest levels

29 Raina P. Kościół katolicki a państwo w świetle dokumentów 1945-1989: in 3 vols. Vol. I: 1945-1959. Poznań, 1994. P. 408.

30 Sprawozdania okresowe WUKPPiW za rok 1953 (Białystok, Bydgoszcz, Gdańsk, Katowice, Stalinogród, Koszalin, Kielce, Lublin, Łódź) // AAN. GUKPPiW. Ref. no. 10. P. 17.

3174 Catholic newspapers and magazines were published in Poland in 1949, 51 in 1950, 42 in 1952, and only 35 in 1953. See: Stefaniak J. Polityka władz państwowych PRL wobec prasy katolickiej w latach 1945-1953. Lublin, 1998. P. 180. 
of government. The ordinary censor did not create the political line of the office, but implemented the guidelines received "from higher up". Instructions and so-called records were formulated by individual secretaries of the Central Committee, in particular those responsible for propaganda (press, radio and television), culture and science. During the period of Stalinism and the thaw, instructions came from the Mass Propaganda Department (1948-1953), the Press and Publishing Department (1948-1954), and later from the Propaganda and Agitation Department (1953-1956), the Press, Radio and Publishing Department (1955-1956), again from the Department of Propaganda and Agitation (August-November 1956), and the Press Office (1956-1972).

The sources of instructions and guidelines were the Political Bureau, the secretariat of the Central Committee, ministries and state institutions such as GUS, NIK, and even enterprises ${ }^{32}$. The president of GUKPPiW received orders from the $1^{\text {st }}$ secretary, president and vice-president of the Council of Ministers ${ }^{33}$. It was a permanent element of censorship instruction. Some of the instructions were published in the Black Book of Censorship of the PRL thanks to Tomasz Strzyżewski, former censor who escaped to Sweden in 1977 taking away the most important censorship documents ${ }^{34}$. Orders and requests (also by telephone) formulated by ministers were not uncommon. For example, the Ministry of Foreign Trade blocked, among others, information on trade with capitalist states (including the purchase of coffee), the export of raw materials and goods at lowered prices to the USSR, and the addition of hormones to livestock feed ${ }^{35}$. The Ministry of Agriculture withheld information on infectious animal diseases and death of the poultry. The Press Office sent GUKPPiW orders to block information about road accidents, homicides and suicides. The president of GUKPPiW often received orders from the prime minister. The instructional materials also reached GUKPPiW from the General Staff of the Polish People's Army ${ }^{36}$.

One of the censors from GUKPPiW mentioned in an interview published in the 1980s in the illegal "Tygodnik Solidarność" that in the 1950s censorship was less bureaucratic than in the later period, there were fewer entries, hence greater freedom in the interpretation of some instructions. He also stated that "A lot was done on the phone. Various high-ranked people kept calling and giving urgent orders, the trace of which was nowhere to be found"37.

When analysing various materials related to the activities of censors, it is noteworthy that the basis for the censorship interventions were mainly "non-written guidelines", i.e. very general and non-codified recommendations, which gave censors unlimited room for manoeuvre when interpreting specific guidelines. The censors themselves experienced serious problems understanding all the instructions, records and recommendations, hence the large number of training sessions, briefings and unnecessary deletions, etc. combated by the office. It seems that this was also the cause of numerous instructional letters, such

32 About the sources of instruction see inter alia: Gogol B. Przełom czy kontynuacja? Cenzura w obliczu polskiego Października 1956, cz. 1 // Colloquium Wydziału Nauk Humanistycznych i Społecznych. 2016. Vol.4. P. 25-27; Interview with Tomasz Strzyżewski, Polish Section Radio Free Europe, 21 IV 1978. URL: https://www.polskieradio.pl/68/787/Tag/84588 (accessed: 03.09.2020).

33 Kamińska-Chelminiak K. Cenzura w Polsce 1944-1960. P. 20.

${ }^{34}$ Czarna księga cenzury PRL. London, 1977.

35 Kamińska-Chetminiak K. Cenzura w Polsce 1944-1960. P. 21.

36 Ibid.

37 Ja, cenzor // Tygodnik Solidarność. 1981. Vol. 6. P. 15. 
as "Instructional Bulletins", "Training Bulletins", "Informational and Instructional Bulletins", etc. For some censors, including chiefs, it was a challenge to understand complex instructional materials, produced at an alarming pace during the Stalinist era, regulating the functioning of the control apparatus.

It is also worth remembering that most controversial articles that were to be published in the press were read by the $1^{\text {st }}$ secretary of PZPR himself. The ordinary censor did not make any decisions on the printing of articles that raised concerns as to the rightness of the party's propaganda policy. Texts of this type were consulted on several levels. If a controversial article was to be published in the local press, a lower-level censor passed it to the head of WUKPPiW who directed it to the GUKPPiW where it could be consulted with the Press and Publishing Department of the Central Committee. It was similar in the case of cinematography. According to the memoirs of Mieczysław Rakowski, a long-time member of the PZPR Central Committee, the Political Bureau watched films intended for cinema distribution and decided whether they fitted in with the party's current policy. This was the case, for example, with Andrzej Munk's "Zezowate szczęście" ("Bad Luck") which was viewed by almost the entire Political Bureau. This is how Rakowski recalled this event (entry in the journal of February 10, 1960): "Recently they have refused to show Munk's excellent film - 'Zezowate szczęście'. Nobody and nothing can explain to them that the film is not an attack on socialism. Some members of the Bureau (Ochab, Rapacki, Cyrankiewicz, Zambrowski) were for the release of the film, Wiesław and Kliszko were against. The fact that such matters must be decided by the Political Bureau is also a symptom of the abnormal situation that exists in our country. Why don't competent people decide it?" 38

Although the burden of creating the censorship apparatus in post-war Poland was almost fully borne by the employees of the Soviet Glavlit, Polish communists quite efficiently took over the work methodology of comrades from the Soviet Union. The task of the censorship office was to protect the interests of the ruling party and its allies. Comparing the methods of censors' work in the period just after the war and in the years of Stalinism, a significant change can be seen. While shortly after the establishment of the CBKP in 1945 , there were cases when ideologically untrained censors were employed, during the consolidation of the power apparatus at the turn of 1948-1949, the Marxist worldview was a sine qua non condition for admission to the censorship. During the years of Stalinism, the censor became an officer of the ideological apparatus, the most important instrument of the state in the field of mass media control. The motivations for work had to be purely ideological, and the censors were to be characterized by a sense of mission ${ }^{39}$. During the Stalinist period, the rhetoric of the censors also changed, the ongoing "class struggle" in the country was emphasized more and more, and the emphasis was on searching for the internal enemy.

The censorship of the thaw period (1955-1956) caused, among other factors, by Stalin's death, was characterized by a certain paralysis, chaos and disorientation, resulting from the lack of clearly defined expectations of the party towards the control apparatus, which was related to the clash of several factions within it. Although the essence and mechanism of censorship had not changed, the "climate" that accompanied its activity had. In the years of the thaw, censors' decisions were marked by randomness, which led to

38 Rakowski M. F. Dzienniki polityczne 1958-1962. Warszawa, 1998. P. 179.

39 Główny Urząd Kontroli Prasy 1945-1949. P. 16. 
peculiar opinions, interference and the approval of unconventional texts for publication ${ }^{40}$. The progressive thaw changes and the growing criticism of censorship caused confusion ${ }^{41}$. It seems that this was one of the reasons for the publication in the press of such a large group of "non-censored" texts, which during the years of Stalinism would not have had a chance of appearing on its pages.

The literature on the subject shows that in the periods of the thaw, i.e., the liberalization of the political system, the number of interventions usually increased. It was the result of ideological confusion, the disorientation of certain decision-making groups and the censors themselves, conflicts between factions within the party, and other factors. In turn, in the case of the periods of "tightening of the screws" (Stalinism, late 1950s and 1960s, martial law), the number of censorship interventions and confiscations decreased. At that time, press titles and publishing houses were closed or suspended, the possibilities of expressing one's views were limited, alleged and real enemies of the government were repressed, and organizations, associations and discussion clubs were dissolved. The number of communication channels was falling, so did the number of interventions.

\section{References}

Blium A. V. Soviet censorship in the era of the total terror. 1929-1953. Moscow, Akademicheskii proekt Publ., 2000. (In Russian)

Borowiec J. Aparat bezpieczeństwa a wojskowy wymiar sprawiedliwości. Rzeszowszczyzna 1944-1954. Wrocław, Instytut Pamięci Narodowej, 2004. 78 p.

Budrowska K. Literatura i pisarze wobec cenzury PRL 1948-1958. Białystok, Wydawnictwo Uniwersytetu w Białymstoku, 2009, 286 p.

Charczuk W. Instrukcja dla oficerów śledczych Urzędu Bezpieczeństwa z 1945 roku. Wschodni Rocznik Humanistyczny, 2011, vol. VII, pp. 377-378.

Czubiński A. Polska i Polacy po II wojnie światowej. Poznań, Wydawnictwo Naukowe Uniwersytetu im. Adama Mickiewicza, 1998, pp. 256-350 p.

Dudek A., Jarosz A., Friszke A., Machcewicz P. Czym była PRL. Więź, 1996, vol. 2, pp. 109-130.

Eisler J. Co nam zostało $z$ tamtych lat. Dziedzictwo PRL. Warszawa, Wydawnictwo Naukowe PWN, 2016, $174 \mathrm{p}$.

Friszke A. Polska. Losy państwa i narodu 1939-1989. Warszawa, Wydawnictwo Iskry, 2003, pp. 161-163.

Gardocki W. Wymiana idei i doświadczeń. Współpraca Głównego Urzędu Kontroli Prasy, Publikacji i Widowisk z Gławlitem. Wschodni Rocznik Humanistyczny, 2014, vol. X, pp. 41-49.

Garlicki A. Stalinizm. Warszawa, Wydawnictwa Szkolne i Pedagogiczne, 1993, pp. 24-26.

Główny Urząd Kontroli Prasy 1945-1949. Ed. by D. Nałęcz. Warszawa, Instytut Studiów Politycznych Polskiej Akademii Nauk, 1994, 27 p.

Goban-Klas T. Literacki Gułag: Gławlit, czyli najwyższe stadium cenzury. Piśmiennictwo - systemy kontroli - obiegi alternatywne. Eds G. Borkowska, K. Stadnik. Warszawa, Biblioteka Narodowa, 1992, vol. 1, pp. 46-59.

Gogol B. Przełom czy kontynuacja? Cenzura w obliczu polskiego Października 1956, cz.1. Colloquium Wydziału Nauk Humanistycznych i Społecznych, 2016, vol. 4, pp. 25-27.

Goriaeva T.M. Blitzkrieg in Poland. Iskliuchit'vsiakie upominaniia... Ocherki istorii sovetskoi tsenzury. Minsk, Moscow, Staryy Svet-Print Publ., Vremia i mesto Publ, 1995, 107 p. (In Russian)

Jarosz D. Działalność Podstawowej Organizacji Partyjnej PZPR przy Zarządzie Głównym Związku Literatów Polskich w latach 1949-1953 (w świetle akt własnych). Mazowieckie Studia Humanistyczne, 1999, vol. 1, pp. 5-45.

Jarosz D. Polacy a stalinizm 1948-1956. Warszawa, Instytut Historii Polskiej Akademii Nauk, 2000, 6 p.

${ }^{40}$ Budrowska K. Literatura i pisarze wobec cenzury PRL 1948-1958. Białystok, 2009. P. 286.

41 Gogol B. Przełom czy kontynuacja? P. 27. 
Jarosz D. Rzeczy, ludzie, zjawiska. Studia z historii społecznej stalinizmu w Polsce. Warszawa, Instytut Historii Polskiej Akademii Nauk, 2017.

Kamińska-Chełminiak K. Central Office of Press Control / Main Control Office of Press, Publication and Performances - background, audit scope and Staff. Acta Universitatis Lodziensis. Folia Litteraria Polonica, 2017, vol. 45, iss. 7, pp. 309-316.

Kamińska-Chełminiak K. Cenzura w Polsce 1944-1960. Organizacja, kadry, metody pracy. Warszawa, Aspra JR, 2019. $424 \mathrm{p}$.

Kersten K. Stalinizm w Polsce. Tygodnik Solidarność, 1989, vol.3, p. 8.

Raina P. Kościół katolicki a państwo w świetle dokumentów 1945-1989, vol. 1. Poznań, W drodze, 1994, 408 p. Rakowski M. F. Dzienniki polityczne 1958-1962. Warszawa, Iskry, 1998, 179 p.

Roszkowski W. Najnowsza historia Polski 1945-1980. Warszawa, Świat Książki, 2003, 199 p.

Stefaniak J. Polityka władz państwowych PRL wobec prasy katolickiej w latach 1945-1953. Lublin, Wydawnictwo Uniwersytetu Marii Curie-Skłodowskiej, 1998, 180 p.

Torańska T. Oni. Warszawa, Omnipress, 1990, 75 p.

Vladimirov L. "Glavlit": how the soviet censors work. Index, 1972, vol. 1, iss. 3-4, pp. 31-43.

Werblan A. Stalinizm w Polsce. Warszawa, Towarzystwo Wydawnicze i Literackie, 2009, 53 p.

Статья поступила в редакцию 2 сентября 2020 г. Рекомендована в печать 10 декабря 2020 г.

Received: September 2, 2020 Accepted: December 10, 2020 